\title{
Anemone Pulsatilla a Useful Drug Plant
}

\section{Agarwal T*}

Assistant professor, Banasthali vidhypeeth, India

*Corresponding author: Dr. Teena Agrawal, Assistant professor, Banasthali

Vidhypeeth, Niwai, India, Tel: +91-9680724243; Email: tagrawal02@gmail.com

\section{Mini Review}

Volume 2 Issue 6

Received Date: August 21, 2018

Published Date: September 03, 2018

\section{Abstract}

Traditional medicines is the very large term and in includes the Varity of the topics from the herbs to the several other combinations, TK the traditional knowledge is the wide term and it includes the Varity of the topic from the art and the agricultures, it is also known as the indigenous knowledge, the TK has its existence in the local communities, where the TK Passes from one generation to the another by the oral transmission of the knowledge from one generation to the another which was based on the long term experiences. TM is the term which is used for the locally available flora's for the treatment of the many kinds of the disorders, they includes the Ayvervedic medicines, Chinese and japanned medicines and Korean medicines, siddha and the other unani and the homeopathic medicines. Here in this research article we are presenting some of the aspects of the genus Anemone pulsitilla. The species is belonging to the family ranunculaceae family, the genus is also known as the wind flower, Anemone word is taken from the Greek language and meaning of the genus is the wind flower. The plant grows in the windy places. The genus grows in the alpine Himalayas, in the European country in the England and Siberia, the plant parts that is used is the flowering herb.

Keywords: Traditional medicines; Chinese and Japanned Medicines; Korean Medicines; Ayurvedic Medicines; European Country in the England and Siberia

\section{Introduction}

TM is the group of the health practices which are of the long term uses and they are practices over the long period of time. It includes the health practices and the products, the therapy was the plant and animals and the mineral based products and the other things, some of them were the spiritual therapies which were coined for the treatments of the several kinds of the disorders. TM functions as the alterative system of the medicines, which are developed over thousands of the years of the research and work [1-6].

TM is not only the vital sources of the medicine but also it is the main sources of the income for the many of the local peoples of the world. There are many international and national policies in the TM in the several countries by which they save there generation of the wild drugs plants and their products. Here in this reviewed article we are working on the some of the 


\section{Journal of Natural \& Ayurvedic Medicine}

aspects of the drug plant known as the Anemone pulsitilla of the Ranunculacae family [7-12].

The herb Anemone pulsiilla is the herb of the 3-4 meters is height, the fresh leaves are thin and they are palmaltely cutted. The shape of the flower is of the ranunculaceae types and they are of the butter cup shaped. The name pulsitilla is derived from the fact that the herbs are very severs toxins and they cerate the negative pulsation I the human beings.

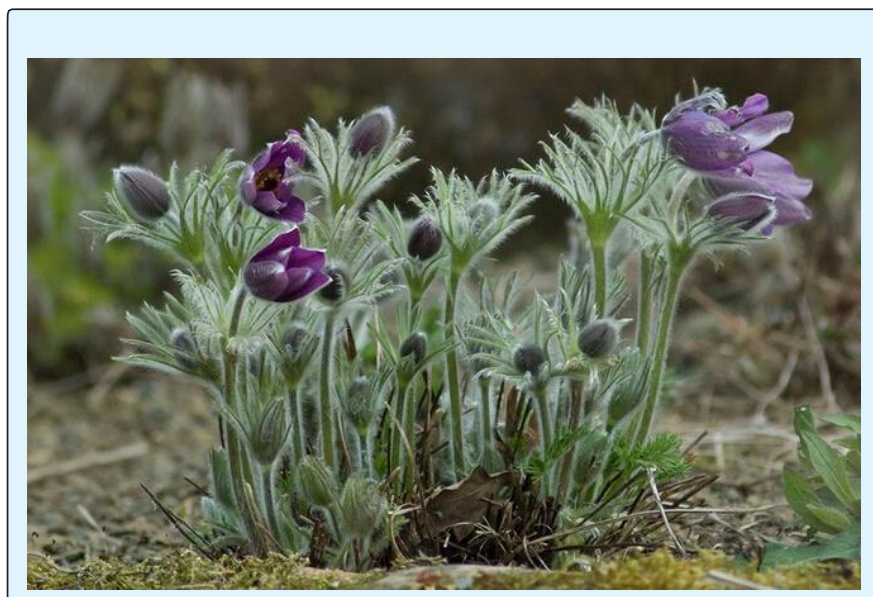

Figure 1: Anewmoe pulsitilla (sources: ebay).

The species is toxic he when the plant is harvested the species is toxic due to the alkaloids pulsing and ranunculin, when it is touched the species is toxic and the very dangerous. The toxins from the leaves and stem are the analgesic and they are antibacterial, sedative and spasmolytic.

\section{Uses}

- The roots is mixed, with milk and given internally.

- Pulsitilla is now particularly used in functions uterine, derangements as leucorrhoea, amenorrhea, dysmerrohea, and other painful action of the pelvic organs.

- They are also used in rheumatism.

- They are used in the nervous headaches.

- It is also used in the bronchitis, asthmas, whooping cough.

\section{Conclusion}

Overall this is the small minireview on the genus Anemone Pulsitilla, the genus s endemic in the Himalayas and the other part of the world, the genus is deterring due to the overexploitation of the plant, the herb is used for the several disorders on the ethnobotanical basis but the toxins are sometimes very toxic and they damage the system, so the people's needs to be very careful, while using the drug for treatment of the disorders [13-18]. the TM and the ATM are the now a day's main drugs for the rural peoples, hey are used for the several disorders, they are cheap and easy to use and safe and they are less toxic in comparison to the other drugs of the chemical origins, the TM and the ATM should be used and they should be conserved for the future uses, however sometimes the eligibility of the TM and the ATM is still the matter of the facts, since they are very toxic and the efficacy is still the question of the debate. The TM and the ATM should be used and they should be formulated in that way the peoples can benefit with them more and more for the suitable ultizatinon of the drugs for the future generations.

\section{References}

1. Foster S, Johnson R (2006) National Geographic Desk Reference to Natural Medicine. National Geographic, Washington.

2. Anonymous (1996) British Herbal Pharmacopoeia. British Herbal Medicine Association, London, pp: 212.

3. Bone K (2003) A Clinical Guide to Blending Liquid Herbs: herbal formulations for the individual patient. St Louis, Churchill Livingstone, Missouri.

4. Wren RC (1982) Potter's New Cyclopaedia of Botanical Drugs and Preparations. Saffron Walden, CW Daniels, UK.

5. Chevalier A (2001) The Encyclopedia of Medicinal Plants. Penguin, St Leonards.

6. Wyk VBE, Wink M (2004) Medicinal Plants of the World. Briza Publications, Pretoria.

7. Felter HW (1983) The eclectic materia medica, pharmacology and therapeutics. Eclectic Medical Publications, Oregon.

8. Murphy R (2000) Homeopathic Remedy Guide. Blacksburg, HANA Press, Virginia.

9. Mills S, Bone K (2005) The Essential Guide to Herbal Safety. St. Louis, Elsevier-Churchill Livingstone, Missouri. 


\section{Journal of Natural \& Ayurvedic Medicine}

10. Bone K (2007) The Ultimate Herbal Compendium-a desktop guide for herbal prescribers. Phytotherapy Press, Warwick.

11. Newall CA, Anderson LA, Phillipson JD (1996) Herbal Medicines-a guide for health-care professionals. Pharmaceutical Press, London.

12. Hoffmann D (2002) Complete Illustrated Guide to the Holistic Herbal. Element, London.

13. Evans WC (2002) Trease and Evans' Pharmacognosy. $15^{\text {th }}$ (Edn.), WB Saunders, London.

14. Brinker F (1997) Herb Contraindications and Drug Interactions. Oregon: Eclectic Institute Inc.
15. Saify ZS, Noor F, Mushtaq N, Dar A (1998) Assessment of Anemone pulsatilla for some biological activities. Pak J Pharma Sci 11(1): 47-53.

16. Duan H (2006) Effect of anemonin on NO, ET-1 and ICAM-1 production in rat intestinal microvascular endothelial cells. J Ethnopharmacol 104(3): 362-366.

17. Menzies-Trull C (2006) Pasque Flower Pulsatilla vulgaris. The Canadian Journal of Herbalism 27(1): 19-20.

18. Khory RN, Katrak NN (1981) Materia medica of India and their therapeutics. Pp: 827. 